NOTISER

132

\section{Nordisk museifestival permanent i Stavanger}

Det är nu fyra år sedan den första museifestivalen ägde rum på Arkeologisk museum i Stavanger. Festivalen samlade drygt 200 deltagare från Norge, Sverige, Danmark och Finland. Över 40 museer och enskilda utställare tävlade med sammanlagt 50 bidrag. Intendent Jan Eric Sjöberg i Göteborg fick festivalens pris FENIX för bästa utställningsidé, för modellen Europa och tjuren. FENIX för bästa utställningsteknik gick till Länsmuseet Västernorrland i Härnösand.

Efter festivalen bestämde vi i samråd med juryn, deltagarna och kollegorna i Stavanger att festivalen skulle äga rum vartannat år. Tanken var då att evenemanget skulle cirkulera i Norden. Helst skulle det vinnande landet arrangera nästa festival, detta för att framhäva festivalens nordiska karaktär. Många uttalade intresse för att överta värdskapet, bl.a. Arbetets museum i Norrköping och återigen Arkeologisk museum i Stavanger. Den gången bestämde vi oss för Norrköping, trogna vår idé om festivalen som ett nordiskt arrangemang. Det blev emellertid inte så. Försöken att få till stånd en godtagbar finansiering misslyckades.

Efter ett tag tvingades vi inse att intresset för festivalen hos de svenska anslagsbeviljande institutionerna inte var stort nog. Planerna fick läggas på is. Ända till dess att det kom en förfrågan från Stavanger igen. Kunde vi inte tänka oss en permanent plats för Nordisk museifestival i alla fall? Till en början hade vi lite svårt att släppa idén om en turnerande festival i de nordiska länderna. Men när allt kom omkring visade sig denna svårgenomförbar. Ingen av oss hade heller möjlighet att arbeta med finansiering och sponsring på heltid. Att placera festivalen i Stavanger skulle garantera Nordisk museifestival en existens för all tid framöver. Arkeologisk museum i Stavanger är ett av Nordeuropas mest framgångsrika museer. Modernt i såväl arkitektonisk som förmedlingsmässig bemär- kelse. Med en bra fungerande infrastruktur och en kompetent personal. Härifrån har det kommit en del revolutionerande utställningsidéer som t ex Museoteket, idag studieobjekt för nordiskt och utomnordiskt museifolk, kort sagt ett museum som har framtiden för sig. Värdskapet för festivalen i maj 1993 genomförde museet på ett effektivt och professionellt sätt. En bättre plats, en bättre värd för den framtida festivalen skulle vi knappast kunna hitta.

Dessutom: det ligger en styrka i att permanenta festivalen såsom vi nu väljer att göra. En permanent värd har mycket goda möjligheter att verka för en långsiktig planering, både för festivalen och för ett utökat deltagande. En permanent värd kan vidare hålla kontakten med museer och kulturinstitutioner i Norden på ett helt annat sätt än en tillfällig arrangör. Detta kommer att gagna en systematisk experiment- och förnyelseverksamhet i museivärlden och därmed festivalens intention. Det är därför med glädje vi ser fram emot den andra festivalen och många kommande på Arkeologisk museum i Stavanger. Sverige har Riksutställningar, Danmark har Museumshöjskolen, Norge kommer nu att få Nordisk museumsfestival.

\section{En festival är en festival är en festival}

Redan före den första festivalen skrev vi att museernas utställningsverksamhet saknar utvecklings- och experimentmöjligheter. Ingenting har ändrats sedan dess. Utställningar diskuteras på konferenser, debatter och seminarier. Men det praktiska arbetet, experiment med nya innehåll och integrationen av innehåll och teknik är eftersatt.

Liksom förra gången vill Nordisk museifestival vara ett forum för det praktiska utställningsarbetet och en slutlig test för hur en utställningsmodell uppfattas. Festivalen skall bidra till:

- att inspirera till att omsätta utställningsidéer till utställning

- att öka lusten att experimentera med nya former och nya innehåll 
- att höja kompetensen och professionaliteten i utställningsarbetet

- att öppna kontaktvägar mellan museer och enskilda producenter

- att göra museiutställningen till ett mera dynamiskt medium

Den andra Nordiska museifestivalen vid Arkeologisk museum kommer att äga rum den 11-13 maj 1998. Det mesta av det förra arrangemanget har vi - i samråd med museet - bibehållit. Det blir således en festivalutställning med deltagarnas modeller och en prisutdelning. Nytt för denna gång är seminarierna i anslutning till festivalutställningen.

Programmet kommer att se ut på följande sätt:

Första festivaldagen bygger de tävlande upp sina modeller till den gemensamma utställningen. Information om eventuell begränsning av modellernas storlek liksom om övriga villkor för deltagande utgår någon gång i höst. Men detta kan sägas redan nu: varje tävlande bidrag (tredimensionellt) åtföljs av en verbal förklaring och foton av modellen. Texten och fotona skall vara museet tillhanda en viss tid före festivalen. Detta för att underlätta juryns arbete.

Andra festivaldagen inleds med en genomgång av modellerna i grupper, där även medlemmarna av den nordiska juryn deltar. Parallellt med denna arrangeras seminarier med anknytning till festivalämnet och med beaktande av de utställningsformer och exponeringstekniker som tillämpas i festivalbidragen. Med seminarierna går vi många tidigare festivaldeltagares önskemål till mötes. Viktigt är emellertid att de har anknytning till modellerna och utställningen samt att tävlingen förblir det dominanta inslaget i festivalen.

I seminarierna får deltagarna tillfälle till en mera analytisk diskussion om utställningsämnen, iscensättning och trender i Norden. Detta blir en dag med ett späckat arbetspensum, inte minst för juryn.

Tredje dagen är själva festivaldagen. Den inleds med en gästföreläsning. Därefter delar juryn ut

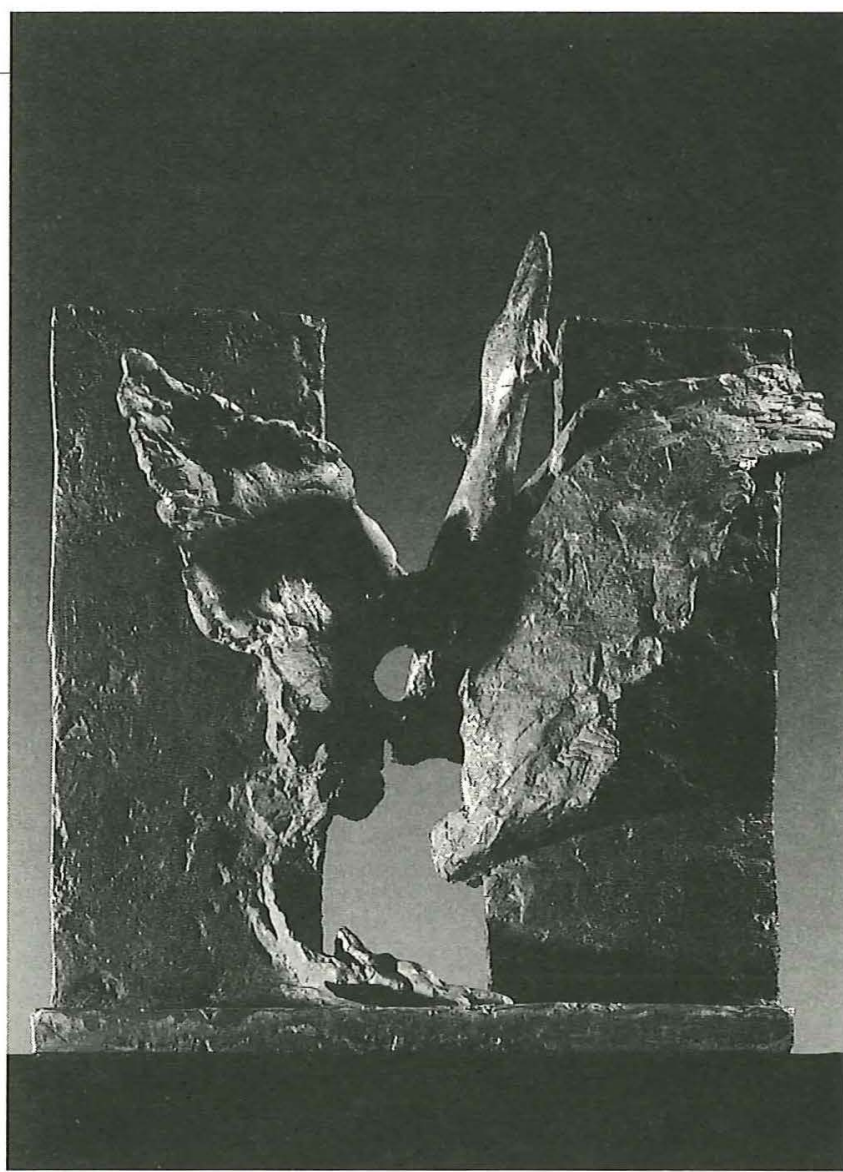

Fägel Fenix har fät stå modell för vairt festivalpris. Den symboliserar det nya som uppstir ur askan, ur traditionerna. FENIX är en bronsstatyett gjord av konstnären Britt Marie Jern i Göteborg.

Foto: Björn Grankvist

FENIX i två prisklasser: en för bästa utställningsidé och en för bästa utställningsteknik. Därutöver delas det ut ett antal diplom för att utmärka speciellt innovativa exponeringar. Att fagel Fenix har fått stå modell för vårt festivalpris är ingen slump.

Den symboliserar det nya som uppstår ur askan, ur traditionerna. FENIX är en bronsstatyett gjord av konstnären Britt Marie Jern i Göteborg

Den första festivalen hade som tema ATT G ÖVER GRÄNSER. Festivaltemat eller mottot denna gång är: VÄNNER OCH FIENDER. ämnet ger fritt spelrum till tolkning av både historiska och aktuella samhällsfrågor, motsättning man - kvinna, nordbo - invandrare, makthavare - folk, arbete - arbetslöshet. Det står deltagarna fritt att tävla med ett bidrag till festivaltemat eller i "obunden klass", dvs med fritt valt tema. Detta kommer inte heller att inverka på möjligheterna att vinna en FENIX. Vi tycker 
134 emellertid att den gemensamma festivalutställningen kan bli ganska spännande med tematiska bidrag. Inte minst är det en god övning för de tävlande att tillverka modeller till ett bestämt ämne. Det är ju så det går till i praktiken vid museerna.

När vi nu kommer att få en permanent museifestival i Norden hoppas vi att den blir en integrerad del i den museala verksamheten, ett återkommande arrangemang där museer och enskilda utställare kan testa sina idéer och experimentera med nya. I denna bemärkelse förenar festivalen både kontinuitet och mobilitet. Allt detta för att utställningen som medium inte skall halka efter i den annars så expansiva och accelererande medieutvecklingen. När vi 1993 förannonserade den första museifestivalen i de nordiska museitidskrifterna skrev vi att idéer har sin egen dynamik, att festivalen i framtiden kommer att leva sitt eget liv. Så har det redan blivit. Arkeologisk museum i Stavanger har nu gett oss och alla intresserade deltagare möjlighet att placera ett nytt nordiskt projekt på den museala kartan och att börja ett inspirerande samarbete i Norden med förnyelse och skapande $\mathrm{i}$ centrum. Så låt gärna redan nu tankarna kretsa kring VÄNNER OCH FIENDER.

Inga Lundström - Gundula Adolfsson

Odd Heide Hald: Museologisk bibliografi. Norsk Museumsutvikling. Oslo 1997. ISBN 82-90935-31-5.

Museologi-begreppet har mött åtskillig skepsis i det nordiska museisamhället genom åren (se härom t.ex. John Aage Gjestrum i Nordisk Museologi 1995/2). Det kan därför betecknas som ett anmärkningsvärt genombrott när Norsk Museumsutvikling publicerar en museologisk bibliografi (och utreder ett museologiskt informationscentrum).

Bibliografin är beundransvärd och kommer säkerligen att bli en oumbärlig nordisk handbok - på samma sätt som på sin tid Harald Nissens i Trondheim utgivna pionjärarbete från 1976 'Samkatalog for museumslitteratur'. Halds bibliografi förtecknar 756 poster fördelade på en avdelning databaser, $C D$ rom, trykte bibliografier, kataloger (284 poster) och en avdelning historiske oversikter, utredninger, oppslagsverker, håndboker, fagpublikasjoner.

Den första avdelningen ger en bred översikt över bibliografiska hjälpmedel som täcker de flesta fackområden av intresse i ett museums arbete. Att den andra avdelningen ter sig ofullständig är snarast ofrånkomligt, men den erbjuder ändå ingångar som kan ge första hjälpen åt den informationssökande.

En särskild förtjänst är den orientering om elektroniskt lagrad bibliografisk information som inleder boken. Den omfattar redan närapå 100 poster. Och torde kräva snarlig uppdatering - såvitt jag förstår finns inte detta arbete själv tillgängligt i elektroniskt lagringsmedium? (PUA)

Michael Lauenborg \& Peter Pentz (red.): Museerne ved årtusindskiftet. Statens Museumsnævn. 1996. ISBN 87-87551-22-5.

Den danska Statens Museumsnævn förefaller ha smittats av den prognoshysteri som det stundande millenieskiftet har utlöst hos många. Postmodernismens fragmentarisering av den nufixerade omvärldsförståelsen framträder här i konfrontation med det offentliga museet som en av det rationella moderna projektets tydligaste uttrycksformer. Konfrontationen beskrivs $\mathrm{i}$ utgivarnas förord $\mathrm{i}$ en slagkraftigt djärv (dansk) metafor med broar, brobyggen och eroderande flyktiga stränder. En citatsammanställning ur en rapport utarbetad av museiexpertgruppen knuten till Nordisk Ministerråd 1993(!) får spegla övergripande visioner. En namnkunnig grupp författare vittnar därefter $\mathrm{i}$ en rad texter om sina, samlade under rubrikerna Museet, tiden og samfundet, Vindue til verden, Museumsinspektoren och Museernes penge - inte alltid så djärvt, ofta mera präglat av gängse sliten museiretorik. Den avslutande översikten med faktiska besked om konkreta projekt fram 